Article

\title{
An Uneven Playing Field: Regulatory Barriers to Communities Making a Living from the Timber from Their Forests-Examples from Cambodia, Nepal and Vietnam
}

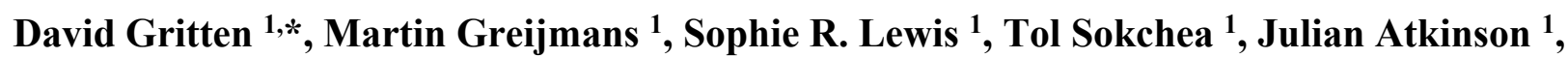 Tan Nguyen Quang ${ }^{1}$, Bishnu Poudyal ${ }^{1}$, Binod Chapagain ${ }^{1}$, Lok Mani Sapkota ${ }^{1}$, Bernhard Mohns ${ }^{1}$ and Naya Sharma Paudel ${ }^{2}$}

1 RECOFTC-The Center for People and Forests, P.O. Box 1111, Kasetsart Post Office, 10903 Bangkok, Thailand; E-Mails: martin.greijmans@recoftc.org (M.G.); sophie.r.lewis@gmail.com (S.R.L.); tol.sokchea@recoftc.org (T.S.); julian.atkinson@recoftc.org (J.A.); tan@recoftc.org (T.N.Q.); bishnu.poudyal@recoftc.org (B.P.); binod.chapagain@recoftc.org (B.C.); lok.sapkota@recoftc.org (L.M.S.); bernhard.mohns@recoftc.org (B.M.)

2 Forest Action, Nakhu, Lalitpur, P.O. Box 12207, 44700 Kathmandu, Nepal; E-Mail: naya@forestaction.org

* Author to whom correspondence should be addressed; E-Mail: david.gritten@recoftc.org; Tel.: +66-2-9405700.

Academic Editors: Wil de Jong, Pia Katila, Glenn Galloway and Pablo Pacheco Received: 7 August 2015 / Accepted: 24 September 2015 / Published: 29 September 2015

\begin{abstract}
Community forestry (CF) is widely viewed as the solution to many of the challenges facing forest management and governance in the Asia-Pacific region. However, it is often felt that $\mathrm{CF}$ is not delivering on its potential. This paper focuses on one possible limitation: the role of regulations in curbing communities' ability to make a living from their timber resources. The work covers Cambodia, Nepal and Vietnam, using policy analyses, national level experts' workshops, and focus group discussions in two CF sites in each country. The results highlight the fact that there are numerous, often prohibitive, regulations in place. One challenge is the regulations' complexity, often requiring a level of capacity far beyond the ability of community members and local government staff. The paper puts forward various recommendations including simplifying regulations and making them more outcome-based, and facilitating key stakeholders, including government and community based organizations, working together on the design and piloting of forest
\end{abstract}


monitoring based on mutually agreed forest management outcomes. The recommendations reflect the belief that for $\mathrm{CF}$ to succeed, communities must be allowed to make a meaningful living from their forests, a result of which would be increased investment in sustainable forest management.

Keywords: Community forestry; commercialization; forest regulations; livelihoods; sustainable forest management

\section{Introduction}

Countries across the Asia-Pacific region have faced numerous challenges related to the management of their forests. The causes (also manifested as impacts) of these challenges have been highlighted as high deforestation rates [1], persistent poor forest governance [2], continued rural poverty [3] and forest conflicts [4]. Governments have taken various initiatives to address these challenges with one of the most prominent being forest tenure reform, including the development of community forestry (CF). Communities, including smallholders, living in and around forests have been provided with various rights, including the right to access the forest, use and withdraw forest products, manage their resources, and exclude others from exercising the same rights $[5,6]$.

An assumption is that by giving tenure rights to communities, they would be better placed to manage their forests sustainably, addressing the deforestation drivers, as well as improving their livelihoods (e.g., [7-9]). While there have been numerous examples from the region where CF has contributed to poverty reduction and enhanced forest quality (e.g., [10-13]), some question the tangible benefits from these initiatives [14]. Development and governmental and non-governmental organizations, as well as academics, have examined why these benefits often fail to materialize. One of the most common issues identified is the narrow focus on non-timber forest products (NTFPs) when pursuing forest development. Restrictions, mostly a large number of regulations, prohibit communities to benefit from timber even though this would bring greater income (e.g., [14-18]). In the context of this paper regulations are "rules prescribed to control the use of forest resources and to assure that the management of these resources conforms to government-defined standards" [19].

Forestry throughout the world is a heavily regulated sector [20], and the Asia-Pacific region is no exception. This abundance of regulations partially reflects the importance of forests in the region (e.g., [21,22]), and how they have been decimated in recent years by unsustainable practices [23], as well as power structures regarding their management [21,24]. Forest conservation and protection and restricting access to land are the main motivations behind the regulations [25]. Pulhin et al. [25], highlight how these regulations strengthen state control over land and forest resources and limit the benefits that communities can garner from their tenure of the forests.

This paper identifies and analyses regulatory barriers in Cambodia, Nepal, and Vietnam that restrict forest communities from making a robust living from forests or developing commercial community forestry enterprises, specifically from the sale of timber and timber products. The paper is structured firstly to provide a brief overview of the status of CF in the three countries, before examining the different regulations on communities to manage their forest and to harvest, process, transport and sell 
the timber, as well as the implications for their attempts to commercialize their forests. The paper examines the results in the context of other work and then goes on to put forward recommendations for addressing the barriers identified.

\section{Materials and Methods}

The work was conducted in Cambodia, Nepal, and Vietnam during 2012 and 2013. The countries were selected based on their differing levels of development and forms of CF. A comparative approach was used to facilitate identification of good practices. Various methods were employed to provide a thorough overview of the regulations and their impacts: this included a literature review and policy analysis, national level experts' workshops and focus group discussions (FGDs) in communities. The aim of the literature review and policy analysis was to examine timber regulations, and how they are applied. The requirements for a community to sell their timber were examined, related to steps for getting tenure, obligations to prepare a management plan, harvesting, transportation and processing of timber, and the timber trade transactions. Where relevant, the specific law or guideline is named in order to facilitate revision if necessary.

The experts' workshops held in each country brought together 10-12 national and international experts to discuss the issues related to the research. The participants included experts from government and individuals involved in the CF development, including those specializing in the sale of timber and non-timber forest products from community forests. The aim of the workshops was to build an understanding of the issues along the path from communities' access to timber, all the way to their ability to profit by selling the timber. The goal was then to use this understanding to identify the barriers to participation in the timber market faced by the local communities. FGDs were held at two CF sites in each country (Table 1) where timber was being harvested (or where there was potential for it to be harvested). The purpose was to collect detailed information from a broad range of relevant community stakeholders on site-specific issues, including costs involved in meeting the regulatory requirements.

Table 1. Location of the focus group meetings in Cambodia, Nepal and Vietnam.

\begin{tabular}{cl}
\hline Country & \multicolumn{1}{c}{ Location of Focus Group Meetings } \\
\hline \multirow{2}{*}{ Cambodia } & $\begin{array}{l}\text { Tbeng Lech Community Forest, Siem Reap Province;Sre Russie, Ampil Commune, } \\
\text { Romeas Heak District, Svay Rieng Province }\end{array}$ \\
\hline \multirow{2}{*}{ Nepal } & $\begin{array}{l}\text { Jhimjhimia and Rajapani Community Forestry User Groups (CFUGs), Rupandehi } \\
\text { district, Western Terai }\end{array}$ \\
\hline Vietnam & Taly village, Ea Hleo District; Cham B village, Krong Bong District \\
\hline
\end{tabular}

\section{Community Forestry in the Study Countries}

\subsection{Cambodia}

Since the early 1990s there has been support from the Forestry Administration (FA) and local government for CF, despite the lack of a legal framework. The Forest Law (2002) provided a regulatory platform and legal recognition for $\mathrm{CF}$ as a way for communities to manage areas of the Permanent Forest Estate. This legal framework was further strengthened with the Office of the Prime 
Minister issuing the Community Forestry Sub-decree to guide the establishment and management of CFs (2003). This was followed by the Ministry of Agriculture, Forestry and Fisheries Prakas (Regulation) on Community Forestry Guidelines (2006). In 2010, CF was incorporated as Programme 4 in the National Forest Programme 2010-2029. This broadened CF to encompass a variety of different models by which rural people could engage in, and benefit from, forest management.

As of December 2012, 229 communities had a Community Forest Agreement (CFA) (i.e., tenure), covering 54,354 households and 183,725 ha [5]. As of September 201516 Community Forestry Management Plans had been approved by the FA, the first of which was approved in October 2012.

\subsection{Nepal}

The National Forest Plan (1976) laid the foundation of CF in the country by recognizing the need for local people's participation in forest management [26]. The Master Plan for Forestry Sector (MPFS), prepared in 1988, spurred the development of CF by including it among its six primary development programs. Building on early successes and decentralization policies, CF expanded rapidly throughout the 1990s under the auspices of the Forest Act (1993), Forest Regulations (1995), and the CF Guidelines (1999) [26]. The Local Self Governance Act (1999) also strengthened the devolution of rights by reinforcing principles of bottom-up planning and consultations, which drove planning processes in forestry sector [27].

According to the Community Forestry Division of the Department of Forest, as of December 2014 1.7 million hectares of forest were managed by 18,133 CF user groups (CFUGs), equivalent to approximately $27 \%$ of Nepal's forest being managed by roughly $35 \%$ of its population [28]. A CFUG is an autonomous body with forest management, withdrawal, access and exclusion rights, which are based on an approved forest management operational plan (OP) with the government (Forest Act 1993).

\subsection{Vietnam}

In the early 1990s, Vietnam began seeking the involvement of non-state actors, particularly local communities, in forest management. The Forest Protection and Development Law (1991) provided a legal framework for allocating forests to individual households. The 1993 Land Law allowed the land user to obtain a long-term (50 years) renewable land-use title, also known as a Red Book Certificate. In addition, the law officially gave the titleholder five rights: to exchange, transfer, inherit, mortgage and lease. These two laws laid down the basic framework for the emergence of CF in the country.

Following the legal framework initially established by these two laws, the government issued various policies guiding the implementation of the forest allocation process. In January 1994, Decree 02/CP was issued, providing a framework for transferring forest management rights from the state to households. Experiments in community-based forms of forest management during the 1990s contributed to the legal recognition of community land tenure (under the 2003 Land Law) and community forest tenure (under the 2004 Forest Protection and Development Law).

By the end of 2013, 3.94 million ha (around 29\% of the total forest area) is under the management of local people, either individual households or collectives [5]. 


\section{Results}

\subsection{Tenure Certification Process}

The research processes in each country highlighted a few concerns regarding the requirements for getting tenure (Table 2). The concern in Cambodia, for example, was that the Community Forestry Agreement may be terminated prior to the expiration date based on one or more conditions identified by the Royal Government of Cambodia that there is another purpose which provides a higher social and public benefit to the country (Article 28, Sub-Decree on Community Forest Management, 2003). If the government decides that a $\mathrm{CF}$ is in an area where they would like to develop another project, the CF can be taken away and the community can possibly also be displaced. In the absence of any notion of due process or compensation for loss, this was perceived as a barrier to the development of CFs, amongst others, particularly in more accessible and populated areas. This is compounded by the concern that the government will revoke the $\mathrm{CF}$ from communities acting in any way that may seriously damage or carry out any misconduct in managing the CF (Article 32, Sub-Decree on Community Forest Management, 2003). However, at present no CF Agreements have thus far been terminated using this method.

Table 2. Details of tenure certification process for each country studied.

Country Process

Detailed in the National Forest Program (2010-2029) and the 2006 Prakas (Community Forestry Guidelines), the following steps are required to attain a CF Agreement:

1. Identification of the potential CF area(s). This involves local and central Forest Administration (FA) and Ministry of Agriculture, Forestry and Fisheries (MAFF), and local authorities and NGOs, and the community.

2. CF establishment. Interested communities submit a formal application, certified by village head, to commune and district councils.

3. Information gathering. A working group is established comprised of the FA, the community and NGO representatives, to collect information about the community and the use of forest resources, and a report is developed that will serve as the basis for future

Cambodia management planning.

4. Establishment of CF Management Committee (CFMC).

5. Preparation of by-laws of CFMC.

6. Demarcating the forest boundary. With the assistance of FA and/or NGOs, as needed, the boundary of the CF is demarcated using GPS. This involves community members, as well as representatives from adjacent villages, in order to avoid conflicts.

7. Preparation of CF regulations. CF regulations are developed by the CFMC with assistance from the FA and/or NGOs.

8. Preparation, submission and approval of CF Agreement. The Agreement is prepared by FA Cantonment and signed by the CFMC. The FA Cantonment or other authority are granted the authority for signing such agreements. 
Table 2.Cont.

\begin{tabular}{|c|c|}
\hline & Process \\
\hline Nepal & $\begin{array}{l}\text { The Forest Regulation (1995) and CF Development Guideline (2009) describe the CF } \\
\text { handover process: } \\
\text { 1. Written request to District Forest Office (DFO) by interested forest users to manage their } \\
\text { accessible forest they have been traditionally using as Community Forest (CF) } \\
\text { 2. With technical and other forms of support from DFO, CFUG formation and preparation of } \\
\text { CFUG constitution by forest users } \\
\text { 3. Application to DFO by CFUG for registration } \\
\text { 4. Registration of CFUG by DFO and issuance of CFUG registration certificate } \\
\text { 5. With support of DFO, preparation of Operational Plan (OP) of CF by CFUG } \\
\text { (includes survey, demarcation of forest area, forest inventory and calculation of annual } \\
\text { increment) } \\
\text { 6. Submission of OP to DFO by CFUG for approval } \\
\text { 7. Approval of OP by DFO and issuance of CF handover certificate }\end{array}$ \\
\hline Vietnam & $\begin{array}{l}\text { Detailed in Decree } 181 / 2004 / \mathrm{ND}-\mathrm{CP} \text { and Circular } 21 \text { (2014) the forest land allocation (FLA) } \\
\text { process follows six steps: } \\
\text { 1. Developing the allocation options and plan. This is done by People's Committees (PC) at } \\
\text { various administrative levels, with final approval by District PC (based on agreement of } \\
\text { Provincial PC). } \\
\text { 2. Preparation of FLA. PCs at the various levels communicate the plan for FLA. Steering } \\
\text { committees and forest allocation committees are established. Any communities, who wish to } \\
\text { apply, have to organize a community meeting in which } 70 \% \text { participants agree to submit } \\
\text { the application. } \\
\text { 3. Submission of FLA application. Communities prepare and submit application to Commune } \\
\text { PC. The Commune PC is responsible for checking the eligibility of the application and send to } \\
\text { relevant district agencies } \\
\text { 4. Verification. District relevant agencies verify the application with technical support from } \\
\text { experts and submit the application to district PCs. } \\
\text { 5. Decision making. District PCs make the final decision. } \\
\text { 6. Implementation: Commune PCs will be responsible to inform communities. }\end{array}$ \\
\hline
\end{tabular}

In Nepal a major concern raised was regarding the mandatory provision of Environmental Impact Assessment for handing over forest and revision of operational plans for CF of a certain size (i.e., 500 to 750 ha requiring initial environmental examination and more than 750 ha requiring Environmental Impact Assessment) introduced by Environment Protection Act (1996) and Regulation (1997). The concern was that these exceed the capacity of the community, but also local government staff to conduct.

A few concerns were raised in Vietnam:

1. The process requires detailed technical information at the time of allocation (e.g., demarcation on maps, delimitation in field, area calculations, forest types and status, timber quality). It is difficult for applicants to meet these requirements given their general lack of technical capacity and capital.

2. Most of the forests allocated to communities are of poor quality, therefore, the potential for generation of short-term benefits from timber and other timber forest products as an incentive 
and source of re-investment capital is very limited. Furthermore, the location of allocated forests can also be a problem. If the allocated area borders protected areas user rights to the area may be limited or lost.

\subsection{Forest Management Plan}

The capacity to develop and submit and verify the management plan (Table 3) was flagged as an issue in all countries, being overly demanding and technical for local communities, as well as for local government staff.

Table 3. Details of requirements for development, submission and approval of community forest management plan in each country studied.

\begin{tabular}{ll}
\hline Country & Process \\
\hline \multirow{2}{*}{ Cambodia } & Upon CF Agreement, a CF Management Plan (CFMP) is developed and submitted by the CF \\
& Management Committee to Cantonment Forest Administration for review. \\
\hline & Forest Rules (1995) provide scope for CFUGs to prepare their Operation Plans (OPs). The OPs \\
& define forest conditions, management activities and determine the annual allowable cut for \\
& timber and fuelwood. The OPs are prepared in line with the CF Inventory Guidelines \\
& (2004).Forest Rules (1995) stipulate that a District Forest Office (DFO) needs to conduct a field \\
Nepal & verification of the OP before approving and handing over the forest to a CFUG. The DFO can \\
& also suggest to amending the OP if they feel it is necessary. Upon approval, they issue a \\
& certificate to the CFUG with a bond to the effect that the CFUG will comply with the \\
& conditions that are prescribed. \\
Guidelines for preparing management plans and plans for timber harvesting are outlined in \\
several documents (Decision 40/2005/QD-BNN sets out regulations for timber harvesting in the \\
four types of forests (Production Forests-Natural and Plantation; and Protection Forests- \\
Natural and Plantation) while Circular 35/2011/TT-BNNPTNT sets out the regulations \\
according to two types of forests (natural forest and plantation forest).). Plans for commercial \\
exploitation of natural forests have the most requirements while guidelines for other forest \\
types are more straightforward.
\end{tabular}

In Cambodia training is provided for communities to address the capacity gaps; however, they are often poorly attended. This is often due to the lack of incentives provided and the perception that the prospects of having an approved CFMP and developing forest-based livelihoods appears distant, particularly as many CFs are located in degraded forests. One immediate effect on the forests is that efforts to control illegal logging by community members are minimal at best, partly due to the lack of funding for forest protection without CFMP approval.

The issue is compounded by the Forest Administration's (FA) lack of formalized operational guidelines and technical and financial capacity to review the CFMPs at both the national and cantonment levels. According to Sub-Decree on Community Forestry Management, an official decision on the approval of the CFMP should be given by the FA within 90 working days. In practice, according to the expert workshop participants, in some cases years have passed without approval. 
In Nepal, the lack of adequate human resource at the disposal of the DFO to, for example, calculate growing stock and annual allowable cut, has led to a problem of sampling errors. Anecdotal evidence suggests that sampling errors are a scale of $10 \%-50 \%$; leading to DFO staff often erring on the side of underestimation. Given this, there is good reason to question the reliability of the OPs being produced. At the community level the technical challenge of completing the OP is one of the reasons that many OPs have not been renewed as required every 5-10 years. As of 2014 an estimated $20 \%-25 \%$ of OPs have lapsed (Workshop on Capacity Develop Needs Assessment for Community Forestry in Nepal. Kathmandu, 27 August 2015).

In Nepal, one finding from the FGD was that the estimated costs to prepare an OP are 100 person-days and NPR 30,000 (USD 342) for an average sized forest (roughly 85ha). A minimum of 60 person-days is estimated for completion. This includes the time of one forest technician, one forest guard and two assistants from the CFUG working together on the forest inventory and approval process. The estimates were, however, higher in the expert workshop if the CF had to comply with the Environmental Impact Assessment. There was also a feeling that the time required of the community was also under-estimated. In Vietnam the estimated costs were USD 1000-1500. This is a reflection of the fact that invariably local communities are not trained foresters so they must hire a consultant.

\subsection{Harvesting}

The requirements for harvesting from community forestry (Table 4) also raised some concerns. In Cambodia no communities are yet able to harvest timber for commercial purposes. This can only occur five years after approval of CFMP (Article 12, Sub-Decree on Community Forest Management, 2003), with the first CFMP being approved in October 2012. Nevertheless, faced with these requirements, community informants suggested that they see the costs associated with compliance as excessive, even feeling that revenues would be significantly higher from illegal rather than legal logging.

Table 4. Details of requirements for conducting harvesting in community forests in each country studied.

\begin{tabular}{ll}
\hline Country & Process \\
\hline \multirow{3}{*}{ Cambodia } & Harvesting within CFs requires permits that: (i) set the annual harvesting quotas for forest \\
& products \& by-products; (ii) authorize the harvest of the forest products \& by-products and; (iii) \\
& set the harvest quota of forest products \& by-products (Article 96, Law on Forestry, 2002). \\
& Harvesting for commercial purposes requires a permit issued by the Forest Administration \\
& (Article 24 \& 25, Law on Forestry, 2002). \\
\hline & There are no specific policies to regulate CF timber harvests as the 1995 Forest Regulations \\
& clearly state that CFUGs can harvest timber from CFs on the basis of approved OPs. However, the \\
& DFO officers commonly encourage CFUGs to adopt the government's guidelines for harvesting in \\
& government-managed forests (Forest Product Collection and Sale/Distribution Guidelines 2002). \\
In accordance with the guidelines (especially Guidelines 2002, Guide 4), the CFUGs harvesting \\
operations follow five steps: (1) Application to DFO for tree marking; (2) DFO's decision for \\
marking; (3) Marking in the field; (4) Application to the DFO for a timber harvest permit; (5) \\
Issuance of harvest permit.
\end{tabular}


Table 4. Cont.

\begin{tabular}{ll}
\hline Country & Process \\
\hline & Government policy differentiates between natural forests and plantations regarding harvesting \\
& timber. The regulations for the harvesting of timber in natural forests for economic purposes are \\
& complex and costly to apply; Including (1) Approval of harvesting plan by the District People's \\
& Committee (Circulars $87 / 2009 / T T-B N N P T N T$ and $70 / 2011 /$ TT-BNNPTNT); (2) Assignment of \\
Vietnam & quota; (3) Issuance of harvesting license; (4) Harvest operations - the forest owners harvest the \\
& timber themselves or contract another entity to do so; (5) Verification and extraction of harvested \\
& timber; (6) Implementation of post-harvest management activities (e.g., regeneration) as per \\
& approved management plan. The policy also sets the minimum standing timber volume in the \\
& forest where harvesting can take place (which is at least $110 \mathrm{~m}^{3}$ per hectare).
\end{tabular}

In Nepal the feeling was that those carrying out harvesting lack adequate training and knowledge of safety measures. Harvesting operations are inefficient and waste is high; a study by Kelly and Aryal [29] showed that the recovery rate of sawn timber was just $40 \%$ of actual volume of log, which compares unfavorably with the anticipated 50\%-60\%. Many CFUGs felt that DFO technical support focuses more on meeting administrative formalities than providing actual technical guidance to help improve the efficiency of the harvesting operations. Although DFO is the key governmental organization to support the activities of CFUGs, DFOs not have the responsibility to provide technical support on forest harvesting operations, therefore, the DFO focused only on related regulatory requirements such as marking trees and overseeing transportation of felled logs rather than providing technical support needed to the community for minimizing wastage of timber and damage to their forest during harvesting operations.

In Vietnam harvesting of timber from plantations is relatively straightforward, particularly when the plantations are established by villagers' and located in a production forest area. In natural forests, the issues are firstly that the forests allocated are invariably of poor quality, and secondly that the focus is more on protection.

\subsection{Transportation}

In Nepal the feeling was that the requirements for transportation (Table 5) were highly bureaucratic, carrying both implicit and explicit transaction costs that affect timber pricing. The need to acquire a permit from the DFO for each step (e.g., marking trees, logging, and collecting logs from the depot, selling logs and transporting them to sawmills) places a great burden on both the community and DFO staff. Additionally, other costs that the buyers often encounter during transportation (e.g., local gangs demanding payment to allow timber to pass, pay off of checkpoint officials to avoid fines) must inevitably be factored into the price paid to the CFUG for its timber. 
Table 5. Details of requirements for transporting timber from community forests in each country studied.

\begin{tabular}{ll}
\hline Country & Process \\
\hline \multirow{3}{*}{ Cambodia } & $\begin{array}{l}\text { Separate permits are required for transport quotas and the transport of forest products and } \\
\text { by-products (Article 26, Law on Forestry, 2002). Significant fines are in place for failure to } \\
\text { comply (Article 96, Law on Forestry, 2002). }\end{array}$ \\
\hline & Timber transportation from CFUG depot to the market must: (i) follow the criteria for sales \\
& established in the OP; (ii) be transported within 21 days from the date of approval of the tender \\
& (Forest Regulations 1995: Rule 35 and Guideline 2002, Guide 16). A transportation permit, \\
Nepal & specifying the route and vehicle number, is jointly issued by the DFOs and CFUGs. Both \\
& organizations also mark each log. The DFO's representative is also required to put a seal on the \\
& vehicle with a representative of the timber buyer present. At the final destination, the seal must be \\
broken in the presence of a local Forest official.
\end{tabular}

In Vietnam the concern was that the updated regulations were biased towards timber from companies. Private companies need only the Forest Office stamp whereas the communities must also have the invoice showing the timber source together with the timber record. Additionally, there was a general feeling of the lack of clarity in the regulations for communities seeking to obtain timber transport licenses.

\subsection{Processing}

In Nepal the regulations regarding processing (Table 6) were heavily criticized as being impractical. Transportation costs are high as sawmills tend to be far from the CFs. The inability to semi-process logs on or near the felling site encourages CFUGs to sell unprocessed logs directly to timber traders, thereby limiting the opportunity for value-added processing.

Additionally in Nepal timber grading, done by government staff, is a relatively new requirement and again is seen as a barrier. Logs are graded based on criteria such as girth, length, form and number of defects. The price of logs varies by grade. As there is not yet a fully standardized approach for grading, a significant degree of subjectivity is involved. Under such conditions, there is an increased potential for corruption. 
Table 6. Details of requirements for processing timber harvested from community forests in each country studied.

\begin{tabular}{ll}
\hline Country & Process \\
\hline & Communities are prohibited to establish and operate any type of processing facility for forest \\
& products or by-products within the boundaries of the Permanent Forest Reserves (State forest \\
& owned by the Royal Government of Cambodia) or within five kilometers of the boundary \\
& (Article 30, Law on Forestry, 2002). Permits are required to establish and operate any type of \\
Cambodia & processing facility for forest products or by-products (Article 25, Law on Forestry, 2002). \\
& Penalties of incarceration and fines are indicated for (i) use of chainsaw without permission of \\
& the Head of Forest Administration; (ii) the import of machinery, vehicles and chainsaws without \\
& appropriate approval (Article 99, Law on Forestry, 2002) (iii) processing unpermitted raw \\
& materials (Article 96, Law on Forestry, 2002). This has implications also for transportation. \\
& CFUGs may process logs, but the establishment and operation of sawmills require prior \\
& approval from the DFO. Sawmills must be located outside the forest (3 km away in the Terai \\
& and 1.5 km away in hills and mountains), in order to minimize illegal activities and allow for \\
easier monitoring by relevant authorities (Letter of MFSC dated 23April 2007). CFUGs are & \\
permitted to saw timber for internal use at sawmills located nearby if approved in advance by \\
the DFO (CF Guidelines, 1999).
\end{tabular}

In Vietnam the government encourages non-state actors to develop forestry product processing enterprises by making low-interest loans available and providing favorable tax policies. The regulation stipulates that forest product processing companies in rural areas are a focus area for investment (Decree 61/2010/ND-CP). Additionally households and individuals in rural areas that are involved in production or services related to forest products are able to obtain low-interest loans of VND 50 million to 200 million ( $\approx$ USD 2400 to 9600 ) from credit organizations (Decree 61/2010/ND-CP). This is an opportunity for households and individuals to access capital to develop enterprises related to forest products and processing. However, the Decree does not extend to communities as groups, only to cooperatives. Accordingly, unless communities and household groups organize themselves into cooperatives, they cannot access loans from formal credit institutions.

\subsection{Selling}

In Cambodia, despite the fact that no timber has yet been sold, there was concern regarding ambiguous and complex requirements for selling timber (Table 7) - for example, the differing taxes for different tree species. The complexity issue was also raised for Nepal, as well as the feeling that the price for timber sold through this process is often well below what it would be in a more transparent and open market. This process is open to collusion among potential buyers, and CFUGs are in a poor position to negotiate should a buyer threaten to back out. Because it is so cumbersome, the incentive is for CFUGs to dispose of available timber quickly (thus cheaply). The transaction costs were also 
highlighted as an issue in Nepal with it being estimated that meeting the requirements for the sale of timber involved 18 person days and costs of NPR 12,000 (USD 137). This includes payment to invitees during the tender process including some sort of informal incentives, as well as fee to the local newspaper for publishing the notice.

Table 7. Details of requirements for selling timber from community forests in each country studied.

\begin{tabular}{|c|c|}
\hline Country & ocess \\
\hline Cambodia & $\begin{array}{l}\text { Permits are required to stock, store, sell or distribute forest products and by-products (Article } 25 \text {, } \\
\text { Law on Forestry, 2002). }\end{array}$ \\
\hline Nepal & $\begin{array}{l}\text { The } 1995 \text { Forest Regulations prescribe where and how CFUGs may sell their timber. Sales are } \\
\text { allowed either within or outside the CFUG, priority is firstly given to CFUG members, second to } \\
\text { district residents, and then to non-district buyers. The OP must specify in advance where the timber } \\
\text { will be sold. DFO approvals are based on the submission of records maintained on timber sales, } \\
\text { income generated by sales, and expenses incurred. Timber sales within CFUGs are governed by } \\
\text { provisions stipulated in the OP. Pricing may differ for households, according to their wealth with } \\
\text { internal CFUG prices between NPR } 200-300 \mathrm{ft}^{3} \text { (USD } 80-121 / \mathrm{m}^{3} \text { ). This compares with timber prices } \\
\text { on the open market that may be significantly higher, i.e., NPR } 800-1100 / \mathrm{ft}^{3} \text { (USD } 322-442 / \mathrm{m}^{3} \text { ). } \\
\text { Once sold, the CFUG management committee ensures that buyers have not resold the timber. The } \\
\text { DFO may approve the sale of surplus timber within a seven-day window to district residents at } \\
\text { government royalty rates or at prices set in the OP. The buyer has to prove residency in the same } \\
\text { district or provide a recommendation letter from the DFO and/or local Village Development } \\
\text { Committee, along with a purchasing application letter. Unsold timber may be sold to buyers } \\
\text { outside the district in accordance with the Financial Procedures Act (1999). Once the CFUG get } \\
\text { permission from the DFO, they can publicly announce a } 21 \text {-day period for a timber auction to } \\
\text { licensed firms. Firms are required to submit copies of their licenses, proof of tax clearance and } \\
\text { proof of deposit ( } 10 \% \text { of the minimum price) along with completed tender-bid forms. A committee } \\
\text { formed by the CFUG facilitates the tender process and approves the highest bidder. The winning } \\
\text { firm(s) must pay the government fee and VAT ( } 15 \% \text { and } 13 \% \text { of timber price respectively). During } \\
\text { the tender period, the CFUG is also required to pay for the presence of a local government and/or } \\
\text { DFO representative. }\end{array}$ \\
\hline Vietnam & $\begin{array}{l}\text { With regards to pricing, there are no specific policies with respect to forestry products, so prices } \\
\text { are set at the market. However, in some provinces the local government determines the minimum } \\
\text { price level over a short period of time (1-2 years) for certain kinds of timber in order to be able to } \\
\text { project future revenues. }\end{array}$ \\
\hline
\end{tabular}

In Vietnam the feeling was that involvement in the timber markets appears to be beyond the capacity of communities. They receive little support from government and their unit production costs are high (economies of scale and regulatory costs) leaving them at a disadvantage. The volumes they can sell are too small to have any leverage or negotiation power with processing facilities, enabling them to set low price for the timber. The lack of access to information on prices and supply and demand forecasts leaves communities at a disadvantage. This is compounded by the fact that communities harvesting and selling timber pay additional fees for developing the harvesting plan (if they employ the consultants), for felling the trees, and for transportation their margins are either 
commensurately reduced as compared to other timber producers or their products must be less competitively priced in the market.

Furthermore, while the government does not require that communities auction their timber, in most provinces, local regulations do. They are forced to put their timber out to tender and are not allowed to sell timber directly. In theory, this could make sense in well-functioning markets with large volumes of timber. However, this is not the case due to a small number of buyers and small amounts of timber tendered by inexperienced sellers. Even in those provinces where the local People's Committee annually set minimum prices for timber, this does not benefit the forest owners as they are unable sell timber directly.

\section{Discussion}

Despite the differing local contexts and interactions of ecological, economic, social and political processes in each country, one can still see common trends in the findings. For example, the results have highlighted that the local communities and forestry officials lack the capacity (knowledge, skills and funding) to comply with regulations. This can be seen, for instance, in formulating, submitting and monitoring management plans. This concern has also been highlighted in other research which also found that often the communities were not following management plans [30,31], though they were still effective in their forest management in terms of the bio-physical forest conditions [30]. The feeling from Toft et al. [30] was that the requirements for the management plans need to reflect the purposes of the forest management as well as the capacity to complete, adhere to and monitor the plans. These conclusions can be applied to numerous areas of the regulations studied here. One implication of the capacity challenges is that, in an environment of weak governance, the regulations, such as those for grading of timber in Nepal, may facilitate rent-seeking, elite capture and even encourage illegal harvesting and unsustainable practices [32,33]. The situation is exacerbated by the fact that communities are often allocated low-quality forest with the timber that they are allowed to harvest being low in volume, which is a further disincentive to them investing in their forests (e.g., [34-36]).

Research in the region on the impacts of CF stress the crucial role of the extent and security of the rights allocated to communities (e.g., [11,12,37]). For example, Seymour et al. [13] highlight that environmental benefits are more likely to occur where the communities are able to use their forest for livelihood options, with their rights being secure and enforced. Timber is the most important among the benefits communities get from their forests, both for domestic consumption and to support their livelihood (e.g., [17,29]). However, as presented in this paper, even where these rights are in place communities still face numerous restrictive regulations to benefit from the timber, a view supported by the literature [25,38].

The disenabling regulatory environment for CF is often compounded by market structures that favor the big players. These include pressures resulting from the development of forest certification, timber legality verification schemes and their challenging procedures (e.g., [18,39-41]). Regulations that increase costs also affect local private sector sourcing from communities, eventually resulting in lower prices for local people $[42,43]$. The large number of regulations not only restrict local communities from maximizing the benefits from sustainable forest management, hence disincentivizing their participation and investment, but they also do not reduce illegal logging (and improve livelihoods) [44]. 
Initiatives such as those being developed in Nepal on group certification [26], or in China on forest farmer cooperatives [45] may be one way forward but still require an enabling environment.

Part of the challenge is the focus of CF. The regulatory framework often disregards the timber economy and its potential. In Nepal, for example, despite timber being major source of income for CFUGs, the timber economy has not gained sufficient support from the state or numerous CF development projects. Instead, these initiatives have emphasized gender and social inclusion, non-timber forest products (NTFPs), and biodiversity [46], failing to strike a balance with commercialization needs. Meanwhile, in Cambodia, the fact that, to date, no community has yet legally harvested timber from their CF leads to the question of whether this is a reflection of government agencies' hesitation in understanding the commercialization potential of CF. The stance of governments is also reflected in how $\mathrm{CF}$ is positioned regarding other land uses. For example, in Cambodia a community is given tenure for 15 years while an Economic Land Concession (ELC), which according to sub-decree 146 of Land Law (2001), is the granting of state private land to private investors for agro-industrial plantations, is granted the concession for 99 years. However, ELCs must comply with various regulations as well; the challenge is that these are often ignored by both the ELCs and government enforcement agencies [47].

In all three countries studied, there was a significant degree of complexity in the regulations and the steps required for compliance, reflected in the costs in Nepal and Vietnam, for example, in developing and getting approval of the management plan. A common denominator was an input-oriented approach to the regulations, focusing on what and how something was done rather than the final results or outcomes. Attempts to foresee and address all potential problems through a series of regulations that focus compliance on inputs to the process have likely led to the proliferation of regulations. The regulations appear as an attempt to micro-manage the complex pursuit of sustainable forest management. One may assume that each "failure" has required a regulatory response in the form of more regulations (e.g., more targeted and restrictive). Instead, a more outcome-oriented approach would be preferred in order to encourage sustainable and affordable or profitable practices (e.g., [30,33]).

While this study set out to allow the comparison of the processes in each country this has not been possible for certain issues. The most prominent challenge has been that of identifying the costs and presenting them in the context of the income from the timber sales. While it was possible to capture most of the costs in Nepal, the data for Vietnam, and even more so for Cambodia, were incomplete. For Cambodia, this partly reflects the fact that communities have yet to be allowed to harvest timber.

There are numerous issues that merit further research regarding the increased prominence of $\mathrm{CF}$ in the timber economy, these include: Firstly, commercialization through timber is not appropriate for all $\mathrm{CF}$, as many are not in a position to commercialize. This could be, for example, linked to size of their forests and market access, but also to their priorities in terms of focusing on other forest products. Future research could examine the potential (including capacities) and interest for timber commercialization for $\mathrm{CF}$ throughout the region. Secondly, the increased prominence of forest communities in the market also brings with it risks that should be examined to help ensure the sustainable success of the CF timber commercialization. These risks could include possible conflict on how to manage the increased prominence of forest management for timber compared to other uses, as well as possible inequitable benefit sharing arrangements in the relationships between the communities 
and their commercial partners. In other words if the regulatory barriers are addressed, this must be complemented by initiatives to improve governance, including strengthening community institutions.

\subsection{Recommendations}

The unique context in each country studied means that there is no common solution for how the regulatory barriers should be addressed. Nevertheless, it is possible to put forward general recommendations that are starting points for moving forward to a "triple win" of improved forest conditions, maintenance of ecological services, and improved livelihoods.

Failure to address the barriers will undermine attempts to sustainably manage forests, as communities are unlikely to invest in their forests if the returns for their investment are not adequate compared to other courses of action. Therefore the overall goal of the suggested re-evaluation of the regulations is sustainability, this includes financial viability. With this in mind, the work provides the following recommendations for governments and the private sector.

\subsubsection{Governments}

- Regulations need to be simple and outcome-based. They must be practical to understand and comply with. This would also make regulations easier and cheaper to administer and monitor (e.g., regarding management plans).

- Regulations should focus less on what is extracted from forests and where and how it is processed, transported and marketed, and more on the state of the forest after harvesting (or at periodic intervals).

- Capacities and economies of scale need to be addressed. This can be done through the development of a support network (e.g., local and national NGOs, research and government institutions) to provide capacity development in such areas as collective marketing and forest inventory.

- Create and update information databases (including details of relevant regulations) that are accessible to communities - not just for training, but also for accessing information regarding, for example, the price of timber and market structure.

- Work with key stakeholders on the design and piloting of an approach of forest monitoring focusing on mutually agreed forest management outcomes.

- Promote policies to attract investment from the private sector, thereby creating market access to communities and possibly developing local infrastructure reducing costs for business operations.

\subsubsection{Private Sector}

- Forestry companies need a stable supply of materials and many are open to outgrower schemes. Engaging local people, where all parties clearly understand the risks as well as the benefits, would improve relations with local communities while, at the same time, giving the communities a stake in companies' success and a market for their timber. 


\section{Acknowledgments}

The work was supported by the Rights and Resources Initiative (RRI), the Ministry of Foreign Affairs Finland (through the ForInfo project), the Norwegian Agency for Development Cooperation (NORAD), the Swiss Agency for Development and Cooperation (SDC) and the Swedish International Development Cooperation Agency (SIDA).

The authors are extremely grateful to the anonymous reviewers and the special issue editors for their invaluable suggestions on earlier versions of the paper.

\section{Author Contributions}

David Gritten took the lead in designing the study and writing the manuscript. All other authors assisted in designing the study and writing of the manuscript. Naya Paudel and Tol Sokchea also coordinated the fieldwork.

\section{Conflicts of Interest}

The authors declare no conflict of interest.

\section{References}

1. Food and Agricultural Organisation of the United Nations (FAO). Forest Resources Assessment; FAO: Rome, Italy, 2010.

2. Food and Agricultural Organisation of the United Nations (FAO). New Challenges New Opportunities: A Summary of Events of Asia-Pacific Forestry Week 2011; FAO: Bangkok, Thailand, 2012.

3. International Fund for Agricultural Development (IFAD). Rural Poverty in Asia, 2010. Available online: http://www.ruralpovertyportal.org/region/home/tags/asia (accessed on 22 May 2015).

4. Gritten, D.; Mola-Yudego, B.; Delgado-Matas, C.; Kortelainen, J. A quantitative review of the representation of forest conflicts across the world: Resource periphery and emerging patterns. For. Policy Econ. 2013, 33, 11-20.

5. Sikor, T.; Gritten, D.; Atkinson, J.; Bao H.; Dahal, G.; Duangsathaporn, K.; Hurahura, F.; Marona S.; Maryudi, A.; Phanvilay, K.; et al. Community Forestry in Asia and the Pacific: Pathway to Inclusive Development; RECOFTC: Bangkok, Thailand, 2013; p.99.

6. RECOFTC. Current Status of Social Forestry in Climate Change Mitigation and Adaptation in the ASEAN Region: Situational Analysis 2013; RECOFTC-The Center for People and Forests: Bangkok, Thailand, 2014; p.10.

7. Berkes, F.; Davidson-Hunt, I.J. Communities and social enterprises in the age of globalization. J. Enterp. Communities 2014, 1, 209-221.

8. Molnar, A.; Liddle, M.; Bracer, C.; Khare, A.; White, A.; Bull, J. Community-Based Forest Enterprises in Tropical Forest Countries: Status and Potential; Rights and Resources Initiative: Washington, DC, USA, 2007; p. 60. 
9. Devkota, R.; Maryudi, A.; Krott, M. Paradoxes of community forestry: Formal devolution covering informal expansion of State control—Cases from Nepal and Indonesia. In Proceedings of the Taking Stock of Smallholder and Community Forestry: Where Do We Go from Here? Montpellier, France, 24-26 March 2010. Available online: http:/www.cifor.org/publications /pdf_files/events/montpellier/scientific-session/Presentations/Session\%206/Rosan\%20Devkota\% 20paper_Community\%20Forestry\%20Conference.pdf (accessed on 28 September 2015).

10. Nagendra, H.; Pareeth, S.; Sharma, B.; Schweik, C.M.; Adhikari, K.R. Forest fragmentation and regrowth in an institutional mosaic of community, government and private ownership in Nepal. Landsc. Ecol. 2008, 23, 41-54.

11. Lambrick, F.; Brown, N.; Lawrence, A.; Bebber, D. Effectiveness of Community Forestry in Prey Long Forest, Cambodia. Conserv. Biol. 2014, 28, 372-381.

12. Pinyopusarerk, K.; Tran, T.; Tran, V. Making community forest management work in northern Vietnam by pioneering participatory action. Land Use Policy 2014, 38, 257-263.

13. Seymour, F.; La Vina, T.; Hite, K. Evidence Linking Community-Level Tenure and Forest Condition: An Annotated Bibliography; Climate and Land Use Alliance: San Francisco, CA, USA, 2014; p. 65.

14. Larson, A.M.; Ribot, J.C. The poverty of forestry policy: Double standards on an uneven playing field. Sustain. Sci. 2007, 2, 189-204.

15. Midgley, S.; Rimbawanto, A.; Mahfudz, I.; Fuazi, A.I.; Brown, A. Options for Teak Industry Development in South-East Sulawesi, Indonesia; Australian Centre for International Agricultural Research (ACIAR): Canberra, ACT, Australia, 2007.

16. Pokorny, B.; Johnson, J.; Medina, G.; Hoch, L. Market-based conservation of the Amazonian forests: Revisiting win-win expectations. Geoforum 2012, 43, 387-401.

17. Gritten, D.; Paudel, N.S.; Luintel, H.; Khatri, D.B.; Atkinson, J.; Bampton, J.; Mohns, B.; Bhandari, K.; Silori, C.; Janakiraman, M. Enabling forest users in Nepal to exercise their rights: Rethinking regulatory barriers to communities and smallholders earning their living from timber. In Forests under Pressure: Local Responses to Global Issues; Katila, P., Galloway, G., Eds.; IUFRO WFSE World Series; International Union of Forest Research Organizations (IUFRO): Helsinki, Finland, 2014; Volume 32, pp. 275-284.

18. Maryudi, A.; Nawir, A.A.; Permadi, D.B.; Purwanto, R.H.; Pratiwi, D.; Syofi'i, A.; Sumardamto, P. Complex regulatory frameworks governing private smallholder tree plantations in Gunungkidul District, Indonesia. For. Policy Econ. 2015, 59, 1-6.

19. Fay, C.; Michon, G. Redressing Forestry Hegemony: When a Forestry Regulatory Framework is Best Replaced by an Agrarian One. For. Trees Livelihoods. 2005, 15, 193-209.

20. Krott, M. Forest Policy Analysis; Springer: Dordrecht, The Netherlands, 2005.

21. Sunderlin, W.D.; Angelsen, A.; Belcher, B.; Burgers, P.; Nasi, R.; Santoso, L.; Wunder, S. Livelihoods, forests, and conservation in developing countries: An overview. World Dev. 2005, 33, 1383-1402.

22. Edwards, D.P.; Larsen, T.H.; Docherty, T.D.; Ansell, F.A.; Hsu, W.W.; Derhé, M.A. Wilcove, D.S. Degraded lands worth protecting: The biological importance of Southeast Asia's repeatedly logged forests. Proc. R. Soc. Lond. Biol. Sci. 2001, 278, 82-90. 
23. Kissinger, G.; Herold, M.; de Sy, V. Drivers of Deforestation and Forest Degradation: A Synthesis Report for REDD + Policymakers; Lexeme Consulting: Vancouver, BC, Canada, 2012.

24. Sinha, D.B. Betrayal or "Business as Usual"? Access to forest resources in the Nepal Terai. Environ. History. 2011, 17, 433-460.

25. Pulhin, J.M.; Larson, A.M.; Pacheco, P. Regulations as barriers to community benefits in tenure reform. In Forests for People: Community Rights and Forest Tenure Reform; Earthscan: London, UK, 2010.

26. Kanel. K.R.; Poudyal, R.P.; Baral, J.C. Current Status of Community Forestry in Nepal; Regional Community Forestry Training Center for Asia and the Pacific Bangkok (RECOFTC): Bangkok, Thailand, 2005.

27. The Ministry of Forests and Soil Conservation. Review of Implementation of the Master Plan for the Forestry Sector: Achievement and Lessons; The Ministry of Forests and Soil Conservation: Singh Durbar, Kathmandu, Nepal, 2014.

28. Department of Forest (DoF). CFUG Database Record; Department of Forest, Ministry of Forests and Soil Conservation, Government of Nepal: Kathmandu, Nepal, 2014.

29. Kelly, M.; Aryal, P. Managing the risks of community-based processing: Lessons from two community-based sawmills in Nepal. In A Cut for the Poor, the International Conference on Managing Forests for Poverty Reduction: Capturing Opportunities in Forest Harvesting and Wood Processing for the Benefit of the Poor; Oberndorf, R., Durst, P., Eds.; Regional Community Forestry Training Center for Asia and the Pacific Bangkok (RECOFTC): Bangkok, Thailand, 2007; pp. 74-84.

30. Toft, M.N.J.; Adeyeye, Y.; Lund, J.F. The use and usefulness of inventory-based management planning to forest management: Evidence from community forestry in Nepal. For. Policy Econ. 2015, in press.

31. Rutt, R.L.; Chhetri, B.B.K.; Pokharel, R.; Rayamajhi, S.; Tiwari, K.; Treue, T. The scientific framing of forestry decentralization in Nepal. For. Policy Econ. 2014, in press.

32. Devkota, R.R. Interests and Power as Drivers of Community Forestry: A Case Study of Nepal; Universitätsverlag Göttingen: Göttingen, Germany, 2010; p. 323.

33. Sunam, R.K.; Paudel, N.S.; Paudel, G. Community forestry and the threat of recentralization in Nepal: Contesting the bureaucratic hegemony in policy process. Soc. Natl. Resour. 2013, 26, 1407-1421.

34. Dev, O.P.; Yadav, N.P.; Springate-Baginski, O.; Soussan, J. Impacts of community forestry on livelihoods in the middle hills of Nepal. J. For. Livelihood 2003, 3, 64-77.

35. Poffenberger, M. People in the forest: Community forestry experiences from Southeast Asia. Int. J. Environ. Sustain. Dev. 2006, 5, 57-69.

36. Anderson, J.; Mehta, S.; Epelu, E.; Cohen, B. Managing leftovers: Does community forestry increase secure and equitable access to valuable resources for the rural poor? For. Policy Econ. 2015, doi:10.1016/j.forpol.2014.12.004.

37. Porter-Bolland, L.; Ellis, E.A.; Guariguata, M.R.; Ruiz-Mallén, I.; Negrete-Yankelevich, S.; Reyes-García, V. Community managed forests and forest protected areas: An assessment of their conservation effectiveness across the tropics. For. Ecol. Manag. 2012, 268, 6-17. 
38. Roshetko, J.M.; Snelder, D.J.; Lasco, R.D.; van Noordwijk, M. Future Challenge: A Paradigm Shift in the Forestry Sector. In Smallholder Tree Growing for Rural Development and Environmental Services: Lessons from Asia; Snelder, D.J., Lasco, R.D., Eds.; Springer Verlag: New York, USA, 2008; pp. 453-486.

39. Purnomo, H.; Arum, G.S.; Achdiawan, R.; Irawati, R.H. Rights and wellbeing: An analytical approach to global case comparison of community forestry. J. Sustain. Dev. 2012, 5, 35-45.

40. Wiersum, K.F.; Humphries, S.; van Bommel, S. Certification of community forestry enterprises: Experiences with incorporating community forestry in a global system for forest governance. Small-Scale For. 2013, 12, 15-31.

41. Giang, P.T.; Thang, T.N.; Lien, D.T.; Trong, N.K.; van Trong, L. Livelihood Impact Assessment of Vietnam's Proposed Voluntary Partnership Agreement. Forest Trends; FERN \& Sustainable Rural Development: Hanoi, Vietnam, 2015; p. 50.

42. Mayers, J.; Vermeulen, S. Company-community forestry partnerships: From raw deals to mutual gains? In Instruments for Sustainable Private Sector Forestry Series; IIED: London, UK, 2002; p. 176.

43. Macqueen, D. Supporting small forest enterprises-A cross-sectoral review of best practice. In IIED Small and Medium Forestry Enterprise Series No. 23; IIED: London, UK, 2008; p.75.

44. Kaimowitz, D. Forest law enforcement and rural livelihoods. Int. For. Rev. 2003, 5, 199-210.

45. Food and Agricultural Organisation of the United Nations (FAO). Success Cases and Good Practices in Forest Farmer Cooperative Organizations in China; FAO: Rome, Italy, 2012.

46. Banjade, M.; Paudel, N.; Karki, R.; Sunam, R.; Paudyal, B. Putting Timber into the Hot Seat: Discourse, Policy and Contestations over Timber in Nepal; Discussion Paper Series 11: 2; Forest Action: Kathmandu, Nepal, 2011; p. 16.

47. Dhiaulhaq, A.; Yasmi, Y.; Gritten, D.; Kelley, L.; Chandet, H. Land Grabbing and Forest Conflict in Cambodia: Implications for Community and Sustainable Forest Management. In Forests under Pressure: Local Responses to Global Issues; Katila, P., Galloway, G., Eds.; IUFRO WFSE World Series; International Union of Forest Research Organizations (IUFRO): Helsinki, Finland, 2014; Volume 32, pp. 205-216.

(C) 2015 by the authors; licensee MDPI, Basel, Switzerland. This article is an open access article distributed under the terms and conditions of the Creative Commons Attribution license (http://creativecommons.org/licenses/by/4.0/). 